\title{
MOTIVASI HIJRAH MILENIAL MUSLIM PERKOTAAN MELALUI DAKWAH DIGITAL
}

\author{
Risris Hari Nugraha, Muhamad Parhan, Aghnia \\ Universitas Pendidikan Indonesia \\ Email: risrisharinugraha@upi.edu,parhan.muhamad@upi.edu, \\ aghni4999@gmail.com,
}

Diterima: 17 Mei 2020 | Direvisi: 18 Juli, 2020 | Disetujui: 31 Agustus 2020

\begin{abstract}
This research aims to investigate the motivation of "hijra" for urban millennial muslim through digital da'wa. Motivation is important as the reason for many people to hijra and everyone has their own motives for hijra.Based on the fact shows that urban millennial muslims are familiar with the word "hijra" and social media, but not all of them use social media as a gate to hijra. They assume that the social media is not yet optimal as a medium for da'wah, because the content presented is not attractive and many media have no clear validity of the source. Researchers use descriptive qualitative and literature studies through questionnaires, then collect information from journals, books and online media to study motivation of urban millennial muslim to hijra. The results of this study proved that using digital da'wa can increase the motivation of the hijrah millennial referering the results of the questionnaire stated $72 \%$ the use of digital media in the spread of da'wah it's optimal.
\end{abstract}

Keywords: motivation, millenial, hijrah, digital da'wa

\begin{abstract}
Abstrak
Penelitian ini bertujuan untuk menyelidiki motivasi hijrah milenial muslim perkotaan melalui dakwah digital. Motivasi menjadi hal yang penting sebagai alasan banyak orang yang berhijrah dan setiap orang memiliki motif tersendiri dalam berhijrah. Berdasarkan fakta dilapangan mengungkapkan bahwa milenial muslim perkotaan familier dengan kata hijrah dan media sosial, namun tidak semua dari mereka menjadikan media sosial sebagai pintu gerbang untuk berhijrah. Mereka beranggapan bahwa penggunaan media sosial belum optimal sebagai media dakwah, karena konten yang disajikan masih kurang menarik dan banyak media yang tidak jelas validitas sumbernya. Peneliti menggunakan pendekatan kualitatif deskriptif dan studi literatur melalui penyebaran kuesioner, kemudian mengumpulkan informasi dari jurnal, buku, dan media online untuk mengkaji motivasi milenial muslim perkotaan untuk berhijrah. Hasil penelitian ini terbukti bahwasanya melalui dakwah digital dapat meningkatkan motivasi hijrah milenial muslim perkotaan berdasarkan kuesioner mencapai $72 \%$ optimalisasi penggunaan media digital dalam penyebaran dakwah.
\end{abstract}

Kata Kunci : motivasi,milenial, hijrah, dakwah digital 


\section{Pendahuluan}

Dewasa ini kata hijrah memang bukan hal yang asing untuk generasi milenial, banyak dari mereka yang menggunakan kata "hijrah" dengan bangganya untuk mencerminkan atas keberhasilan diri dalam mencapai tujuannya. Seperti sering memakai gamis, cadar, jilbab yang panjang dan lebar, dan sebagainya hanya dijadikan sebagai gaya semata. Tetapi banyak juga dari mereka yang tidak menanamkan arti hijrah itu sendiri dengan baik. Sebagaimana kita ketahui bahwa hijrah disini, bukan hanya berpindah dari suatu tempat ke tempat yang lain seperti halnya Nabi Muhammad saw berpindah dari Mekkah ke Madinah, tetapi berubahnya perilaku atau sikap menjadi lebih baik lagi dan meninggalkan segala kedzoliman yang pernah dilakukan masa lalu.

Seperti yang dipaparkan dalam penelitian Qadariah (2018), dalam mewawancarai anggota komunitas "Gerakan Pemuda Hijrah" atau sering dikenal "The Shift". The Shift merupakan wadah yang dimana anggotanya ingin berhijrah dan mendekatkan diri kepada Allah SWT yang pemuda-pemudinya berusia sekitar 20-30 tahun. Dari hasil wawancara tersebut menyebutkan banyak yang masih ikut-ikutan dalam mengikuti kajian ataupun memakai baju syar'i saat akan mengikuti kajian, kemudian masih banyak ditemukan bahwa mereka hanya untuk pamer kepada yang lain bahwa dirinya mengikuti kajian rutin, kemudian dalam pengaplikasiannya mereka belum sepenuhnya mengaplikasikan, karena masih tergiur dengan hal yang bersifat duniawi dan malu ketika mengakui berhijrah serta menyebabkan rasa takut tidak diterima oleh lingkungan sekitar, ketika menggunakan gamis dan khimar saat kuliah atau di rumah.

Teknologi saat ini sangatlah pesat dan efektif dalam menyebarkan sebuah berita atau informasi, apalagi pemuda saat ini sudah tidak asing lagi dalam bermain media sosial. Dakwah sangat penting diberikan untuk menyeimbangkan maraknya kontenkonten yang kurang baik di media sosial. Sehingga pemuda milenial tidak terjerumus dengan kenikmatan sesaat sehingga menimbulkan kemorosatan moral, pola pergaulan yang salah dan tidak memikirkan bagimana kehidupan yang akan dijalani kedepannya.

Dalam menyebarkan dakwah sendiri kepada generasi milenial ini bisa dikatakan sebuah tantangan dan kemudahan. Dikatakan mudah karena saat ini teknologi sudah tersebar dimana saja, didukung dengan masyarakat yang lahir dalam rentang tahun 1981 sampai 1994 yang biasa kita kenal dengan generasi milenial. Maka generasi milenial 
merupakan rentan usia 15 sampai 35 tahun. Generasi tersebut telah akrab dengan berbagai teknologi semisal smartphone, sosial media, dan semua aktivitas yang berbasis daring. Generasi tersebut memandang dunia, tidak dengan nyata tetapi mencarinya secara maya. Seperti komunikasi, transaksi belanja via daring, serta mencari berbagai macam informasi yang dibutuhkan. Kebanyakan generasi milenial melakukan komunikasi di dunia maya dengan terlebih dahulu memiliki akun untuk komunikasi dan bertukar pesan, seperti whatsapp, instagram, twitter, line, facebook, dan media sosial lainnya. (Fitri, 2020).

Dakwah bagi kaum milenial yang disampaikan secara konvensional yang cenderung dominan dengan tradisi dakwah lisan tentu kurang tepat (Sarbani, 2010), karena hal itu kurang menarik, tidak up to date dan kurang efektif (Wibowo, 2019). Dakwah bagi kaum milenial harus dikemas dengan menarik dan memanfaatkan konten digital sebagai medianya, hal ini dilakukan agar dakwah menjadi lebih mudah, tidak terbatas ruang dan waktu serta murah dan terbuka untuk semua orang (Rubawati, 2018). Sehingga sangat perlu bagi pendakwah untuk menggunakan perkembangan teknologi dan media untuk kegiatan berdakwah, yang sebelumnya dilakukan dengan cara konvensional, kini harus diorientasikan secara digital melalui media sosial (Ummah, 2020)

Dengan melihat fakta demikian, sangat mudah dalam menyebarkan dakwah, tetapi menjadi sebuah tantangan juga ketika penyebaran dakwah tidak mengoptimalkan dalam menggunakan media sosial tersebut. Dakwah harus bisa diakses dengan cepat dan mudah yang disajikan melalui content yang unik serta menarik yang disajikan secara daring melalui berbagai macam media sosial. Sehingga, kajian dan cara berdakwah di zaman milenial sangat penting untuk digali lebih jauh, supaya dapat diketahui metode berdakwah yang bagaimana yang harus dilakukan, supaya berdakwah dapat tersampaikan dengan baik dan content dakwah dapat tersampaikan secara menyeluruh. (Habibi, 2018)

Dengan penyebaran dakwah melalui media sosial ini diharapkan generasi milenial dapat termotivasi dalam berhijrah, bukan hanya ikut-ikutan dan pamer saja, tetapi murni dari diri sendiri dan takut kepada larangan Allah sehingga berusaha memperbaiki dan merubah perilaku menjadi lebih baik lagi, yang di aplikasikan dalam kehidupan yang nyata (Parhan \& Sutedja, 2019). Berdasarkan hal tersebut, peneliti ini 
bertujuan untuk mengkaji mengenai apakah dalam penyampaian sekaligus penyebaran dakwah melalui media sosial atau bisa disebut juga dakwah digital ini dapat meningkatkan motivasi milenial muslim dalam berhijrah.

\section{Metode Penelitian}

Pendekatan penelitian yang digunakan adalah kualitatif dan kuantitatif, pendekatan kualitatif digunakan untuk mendeskripsikan hasil penelitian yang ditemukan dan pendekatan kuantitatif digunakan untuk menghitung dan menyajikan data-data yang ditemukan serta disajikan dalam bentuk angka, data, diagram dan tabel untuk kemudian dianalisis dan dideskripsikan. Untuk pengumpulan datanya peneliti melakukan studi literatur, penyebaran kuesioner, kemudian mengumpulkan informasi dari jurnal, buku, dokumen dan media online.

Penelitian dimulai dengan studi literatur dari jurnal, buku, dan media online lainnya. Setelah itu peneliti menyebarkan kuisioner secara online berharap dapat menerima data lebih banyak dan lebih efektif. Selain itu penyebaran kuesioner ini juga bermaksud untuk mengetahui pendapat dari responden mengenai seberapa besar pengaruh media sosial terhadap motivasi hijrah, bagaimana responden pengikut akun media sosial yang terhadap dakwah islami motivasi hijrah, dan bagaimana cara yang digunakan responden untuk mengajak orang lain untuk berhijrah.

\section{Hasil Penelitian dan Pembahasan}

Hasil penelitian didapatkan melalui penyebaran kuesioner secara daring, yang berjumlah 19 pertanyaan, yang di isi oleh 75 orang responden, berdasarkan hasil kuesioner tersebut diperoleh data bahwa dari sejumlah 75 responden, yang mengisi kuesioner jumlah laki-laki sebanyak 21 orang atau sebesar $28 \%$ dan perempuan sebanyak 54 orang responden, atau sebesar $72 \%$ dari jumlah total responden, hal ini dapat dilihat seperti dalam diagram di bawah ini:

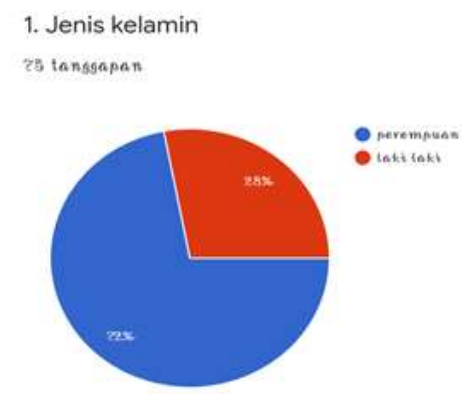


Rentang usia kebanyakan antara 20-25 tahun yaitu sebanyak 76\%, dan 21,3\% berusia 20 kebawah dan sisanya diatas 25 tahun.

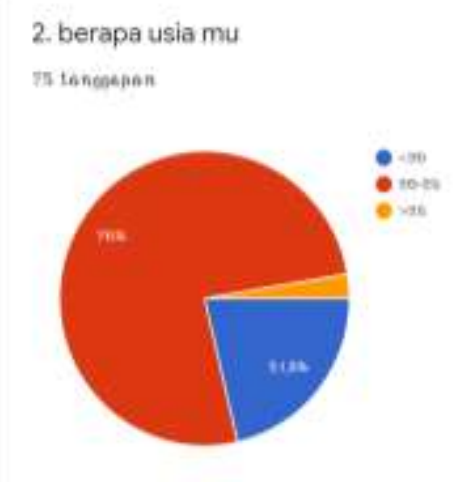

Kebanyakan dari mereka berstatus pelajar atau mahasiswa berkitar 89,3\% atau setara dengan 67 responden, kemudian sebanyak 5,3\% atau 4 orang merupakan pekerja swasta dan sisanya merupakan satpam, ibu rumah tangga, dan lainnya, serta semua responden mengetahui tentang hijrah, seperti diagram di bawah ini:
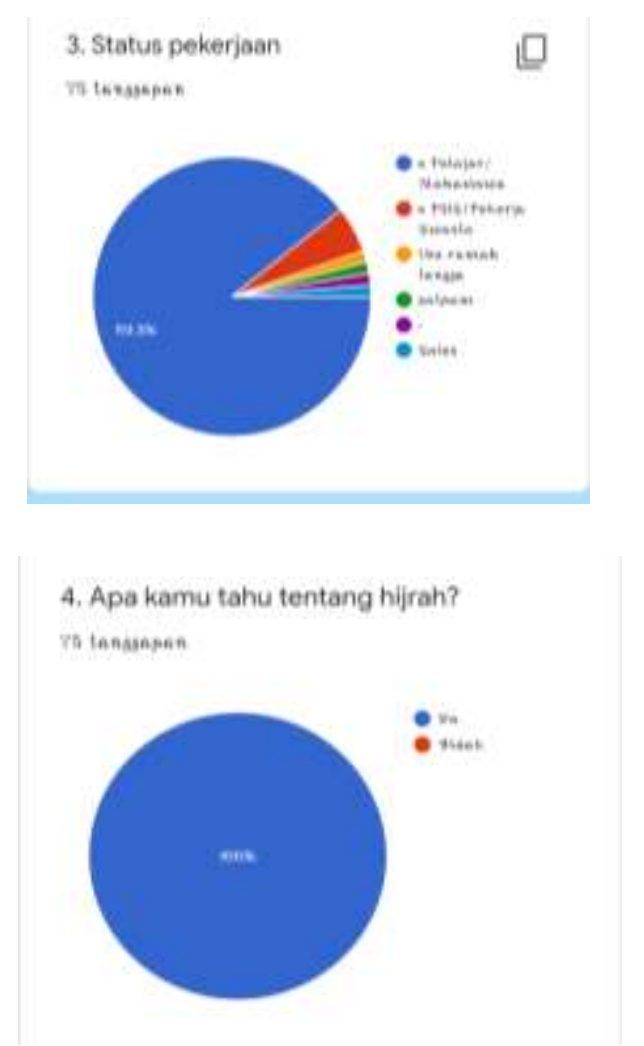

Dari diagram di bawah dapat dapat dilihat sebanyak 56\% mengatakan jika hijrah itu berarti keduanya yaitu berpindah dari satu tempat ketempat yang lainnya dan merupakan perubahan menjadi pribadi yang lebih baik, 41,3\% mengatakan hijrah 
merupakan perubahan menjadi pribadi yang lebih baik dan sisanya mengatakan makna hijrah itui berpindah dari satu tempat ketempat yang lainnya
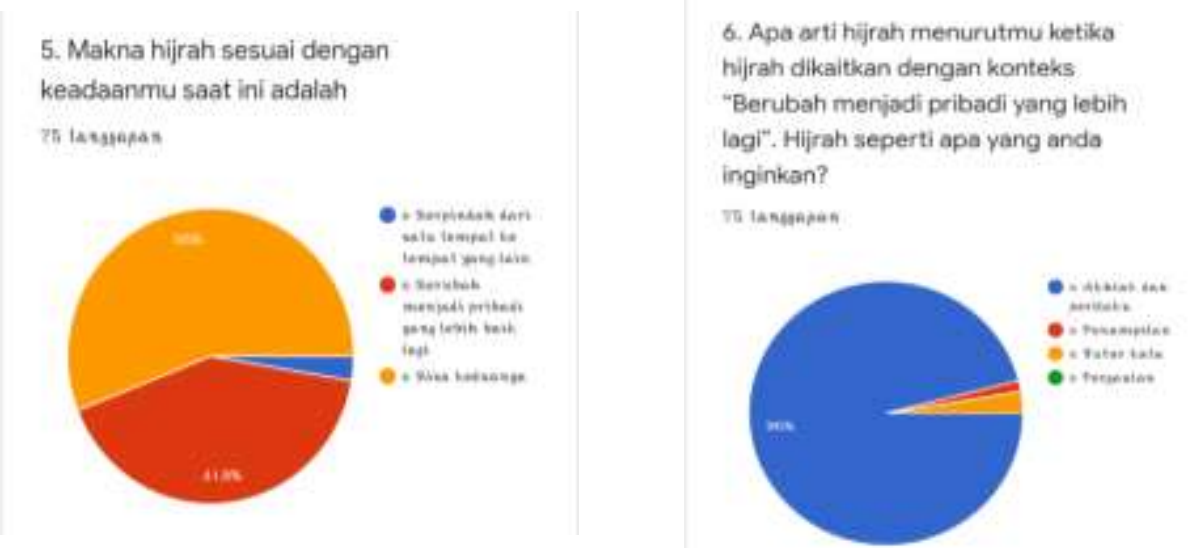

Ketika dikaitkan dengan arti hijrah sebagai perubahan menjadi pribadi yang lebih baik sebanyak 96\% mengatakan hijrah yang dilakukan berdasar pada perubahan akhlak dan perilaku dan sisanya merupakan perubahan penampilan dan tutur kata.

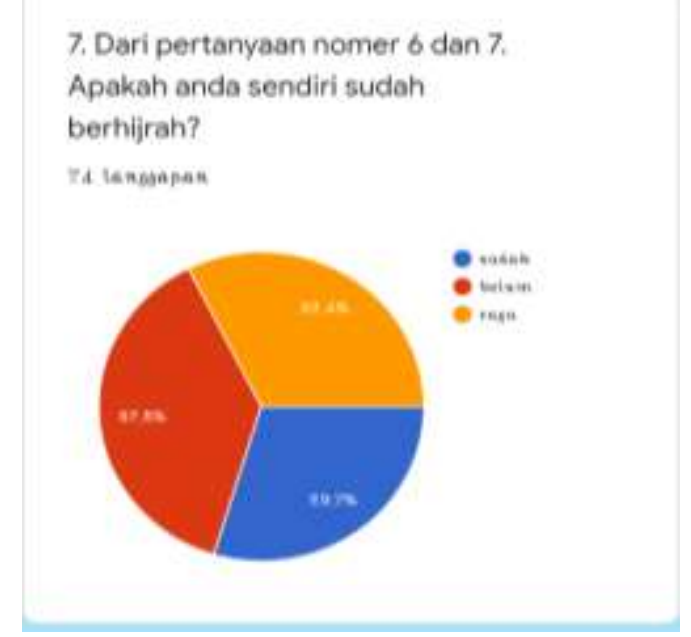

Dari tanggapan diagram di atas dapat dilihat bahwa sekitar $37,8 \%$ atau 28 responden mengatakan jika mereka belum berhijrah, $29.7 \%$ atau 22 responden sudah berhijrah, dan $32,4 \%$ atau 24 responden masih ragu. Secara umum responden kebanyakan mengetahui apa itu hijrah, dan apa manfaatnya, serta bagaimana untuk memulainya, mereka mengetahui bahwa berhijrah dapat terpenuhi syarat-syaratnya dengan cara meninggalkan hal yang kurang baik dan menuju kepada hal yang lebih baik. Hal ini senada dengan Setiawati (2019) yang menyatakan bahwa hijrah memiliki makna yang beragam, berhijrah bisa dimaknai dengan bertekad dalam mengubah pribadi dalam mendapatkan ridha dan kasih sayang Allah Swt. kemudian, berhijrah dapat dimaknai dengan keyakinan dalam hidup. 
Dalam konteks ini pengertian hijrah bersumber dari bahasa Arab yang mempunyai arti berpindah, berpaling, meninggalkan, dan tidak peduli lagi. Makna lebih luas, secara terminologi hijrah tidak hanya bisa dimaknai perpindahan seorang dari satu tempat ke tempat lain saja, tetapi hijrah bisa dimaknai sebagai suatu perjalanan untuk mencari pelajaran, nasehat dan hikmah dalam berbagai bentuknya, seperti; perjalanan ibadah haji, perjalanan untuk bekerja, berbisnis, dalam rangka menuntut ilmu, mengajak masyarakat untuk membela negara dan kunjungan saudara yang berjuang dijalan Allah Swt. Budiono (2019).

Dalam pandangan Syaikh Sya'rawi (Budiono, 2019) secara garis besar, hijrah terbagi menjadi dua macam yaitu:

1. Hijrah Makaniyah yaitu (berpindah dari satu tempat ke tempat lain). Contoh hijrah makaniyah adalah peristiwa hijrahnya Rasulullah dari Makkah ke Madinah serta hijrahnya Nabi Ibrahim dan Nabi Musa.

2. Hijrah Maknawiyah yaitu (mengubah diri, dari yang buruk menjadi lebih baik demi mengharap keridhaan Allah SWT).

Hijrah Maknawiyah dibagi lagi menjadi 4 diantaranya:

a. Hijrah I'tiqadiyah yaitu (hijrah keyakinan), ketika seorang Muslim mencoba meningkatkan keimanannya agar terhindar dari kemusyrikan.

b. Hijrah Fikriyah yaitu (hijrah pemikiran), ketika seseorang memutuskan untuk kembali mengkaji pemikiran Islam yang berdasar kepada sabda Rasulullah dan firman Allah untuk dapat menghindari pemikiran yang sesat.

c. Hijrah Syu'uriyyah, merupakan perubahan pada seseorang yang dapat dilihat dari penampilannya, seperti gaya berbusana dan kebiasaannya dalam kehidupan sehari-hari.

d. Hijrah Sulukiyyah, yaitu (hijrah tingkah laku atau kepribadian). Hijrah ini digambarkan dengan tekad untuk mengubah kebiasaan dan tingkah laku buruk menjadi lebih baik.

Jadi dapat disimpulkan bahwa hijrah adalah meninggalkan suatu perilaku dan perbuatan yang buruk serta memperbaiki atau merubah diri agar menjadi pribadi yang lebih baik lagi. 


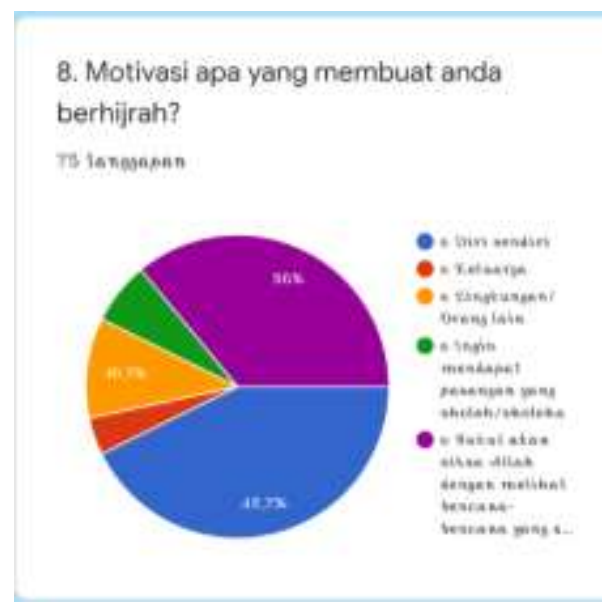

Dari keseluruhan respon mengatakan motivasi mereka berhijrah berasal dari diri sendiri yaitu sebanyak 42,7\% atau sama dengan 32 tanggapan, 36\% atau 27 tanggapan karena takut akan siksa Allah dengan melihat bencana-bencana yang sudah terjadi, dan sisanya 3 tanggapan dukungan keluarga dan 8 tanggapan lingkungan/orang lain serta 5 tanggapan ingin mendapat pasangan yang sholeh/sholehah.

Motivasi menjadi hal yang penting sebagai alasan banyak orang yang berhijrah. Setiap orang memiliki motif tersendiri untuk berhijrah. Menurut Farhan \& Retnawati (2014) menyebutkan motivasi adalah sebuah dorongan untuk dapat memberi energi kepada orang lain dalam melakukan suatu kegiatan, kemudian membimbingnya supaya tercapai apa yang menjadi tujuannya. Selain itu motivasi dapat diartikan sebagai suatu dorongan untuk melakukan sesuatu dimana dorongan tersebut menjadi pembangkit untuk mencapai tujuannya. Menurut Farabuana \& Nurrahmi (2019) mengemukakan dari pengertian motivasi tersebut, terbagi menjadi dua motivasi "motivasi untuk dan motivasi karena", motivasi untuk berorientasi ke masa depan sedangkan motivasi karena berorientasi ke masa lalu" dan dibedakan menjadi dua kategori yaitu dari dalam individu sendiri dan dari luar individu, dimana terjadinya perubahan menjadi lebih baik lagi dari sebelumnya sehingga tercapai apa yang diharapkan dan dihargai oleh orang lain. Farhan \& Retnawati (2014). Sedangkan menurut Makmun (2007) mengatakan, motivasi itu terjadi karena ada dorongan dari dalam jiwa dan dipengaruhi oleh lingkungannya. Dari hal tersebut motivasi terbagi menjadi dua golongan:

1. Motif primer atau yang sering didengar dengan dorongan yang dibedakan menjadi dua yaitu pertama dorongan fisiologis atau bersumber dari kebutuhan organis dan kedua dorongan umum atau bersumber dari luar yang berupa 
rangsangan seperti rasa takut, kasih sayang, dorongan untuk melarikan diri, dan lainnya.

2. Motif sekunder yang lebih berorientasi kepada sesuatu berdasar pengalaman atau bisa juga melalui belajar. Contohnya itu motif sosial dimana individu merasa ingin dihargai, ingin diterima dan sebaganya.

Oleh karena itu setiap gerak perilaku manusia dari segi motifnya mengandung tiga aspek yakni: 1). Motivatingi states; 2). Motivated behavior; dan 3). Satisfied conditions. Jadi dapat disimpulkan motivasi merupakan sebuah bentuk dorongan baik dari dalam diri sendiri maupun luar untuk melakukan sesuatu sehingga menjadi penyemangat untuk mencapai apa yang diinginkan.

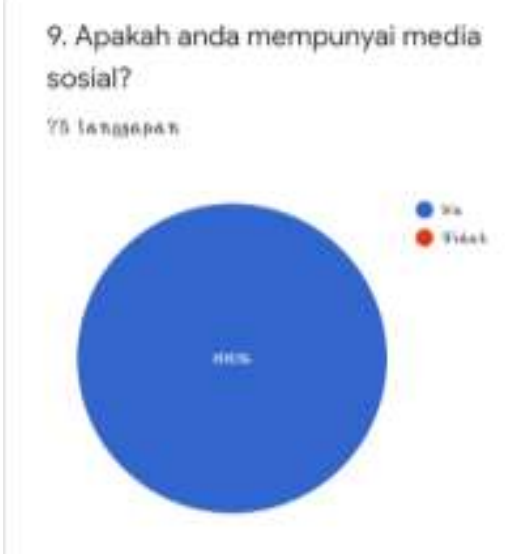

Dari hasil kuesioner secara keseluruhan responden memiliki media sosial.

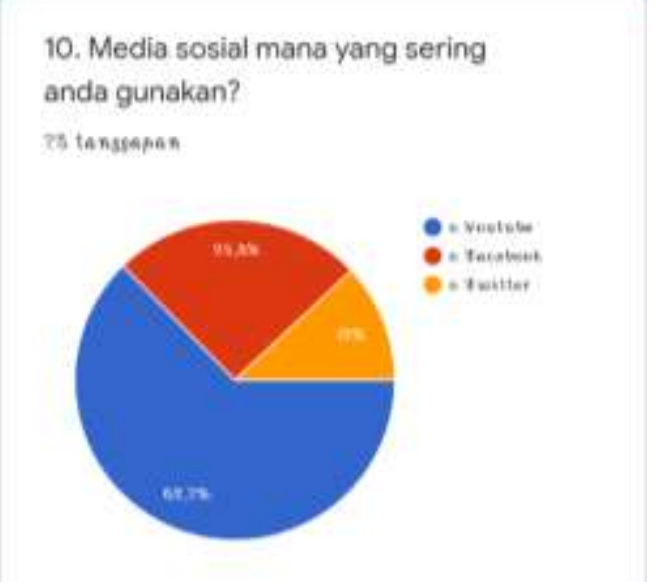

Kebanyakan dari mereka menggunakan media sosial youtube yaitu sebanyak 47 tanggapan atau 62,7\% dan kedua itu media sosial facebook atau sebanyak 19 tanggapan atau 25,5\% dan sisanya $12 \%$ atau 9 tanggapan menggunakan twitter. Media sosial digunakan responden sebagai media untuk mencari informasi, berkomunikasi dan 
melakukan aktivitas dengan tidak tebatas ruang dan waktu. Hal ini sejalan dengan Cahyono (2016) yang mengemukakan bahwa media sosial merupakan sebuah media daring, yang penggunanya dapat dengan mudah berpartisipasi dan berbagi.

Sejalan juga dengan pendapat Setiawati (2019) bahwa media sosial dapat digunakan untuk bersosialisasi antara satu sama lain dan dilakukan secara daring dengan tujuan untuk berinteraksi dengan tidak terbatas ruang dan waktu". Definisi lain dari sosial media juga dijelaskan oleh Van Dijk (Nasrullah 2017) media sosial merupakan sebuah program media yang memfokuskan diri pada eksistensi penggunanya dengan memfasilitasi mereka untuk beraktivitas dan berkolaborasi, sehingga media sosial dapat dimaknai dengan fasilitator online yang menguatkan hubungan antar pengguna sekaligus sebagai sebuah ikatan sosial.

Dari pengertian diatas, dapat disimpulkan bahwa media sosial merupakan media online yang berfungsi sebagai fasilitator karena memudahkan bagi para partisipannya untuk bertukar pendapat, berkomuikasi dan saling berbagi pengalaman tanpa melihat jauh dekatnya si lawan bicara kita. Menurut Kaplan dan Haenlein (Utomo, 2013) juga memberikan tipologi media sosial yang mereka bagi dalam enam jenis yaitu: (1) Collaborative Project seperti wikipedia, (2) Blog, seperti twitter (3) Content Communities seperti youtube, (4) Social Networking Sites seperti facebook dan twitter, (5) Virtual Social Worlds seperti second life, dan (6) Virtuali Game Worlds seperti warcraft.

Media sosial memiliki ciri-ciri antara lain: pesan yang disampaikan tidak hanya untuk satu orang, namun bisa untuk orang banyak; pesan yang disampaikan bebas, tanpa harus melalui gate keeper; pesan yang disampaikan cenderung lebih cepat dibanding media lainnya (konvensional). Habibi (2018). Peran media sosial dalam penyebaran dakwah pada era milenial dan serba digital ini, sangat membantu dan sangat efektif, apalagi didukung dengan canggihnya teknologi dan siapa saja bisa mengaksesnya kapan dan dimana saja. Sehingga untuk dapat mengoptimalkan media sosial ini salah satunya yaitu:

1. Memaksimalkan video dakwah di youtube. Youtube merupakan filesharing untuki semua membernya dimana penggunanya bisa mencari atau upload video rekaman untuk dapat disaksikan oleh jutaan orang. Sehingga diharapkan dakwah yang kita sampaikan atau upload harus dikemas dengan semenarik mungkin. 
2. Replika konten dakwah. Konten serta pesan dakwah harus diviralkan, ataupun disebarluaskan, dengan tujuan agar tersebar luas dengan cepat, cara ini salah satu cara yang efektif dalam menyampaikan dakwah melalui media sosial.

3. Mengemas pesan dakwah. Pesan yang diberikan dalam berdakwah haruslah menarik dan tidak membosankan, seperti penyampaian yang tidak monoton, diselingi oleh video saat sedang menyampaikannya.

Menurut Ngafifi (Fitri, 2017) mengemukakan selain teknologi atau media sosial ini memberikan banyak manfaat, tidak menutup kemungkinan akan berpengaruh negatif pula salah satunya dalam aspek sosial budaya diantaranya:

1. Kemerosotan moral, jika kita tidak bisa memilih dan memilah teman yang berada dalam lingkaran sosial kita, maka akan berpengaruh terhadap moral yang kita miliki.

2. Kenakalan dan tindakan yang menyimpang. Ketika kita sudah salah pergaulan dalam mengikuti konten atau pertemanan dalam media sosial, maka kenakalah dan tindakan yang menyimpang pun tidak akan bisa terhindari.

3. Pola interaksi yang berubah, menyebabkan kita menjadi individu yang antisosial sehingga beresiko mengabaikan orang-orang yang ada di sekitar kita.

Jadi dapat disimpulkan media sosial akan berdampak positif ketika kita menggunakannya dengan bijak dan tidak berlebihan, tetapi sebaliknya media sosial akan berdampak negatif ketika kita sudah mulai ketergantungan dan cenderung mengabaikan kehidupan nyata kita.

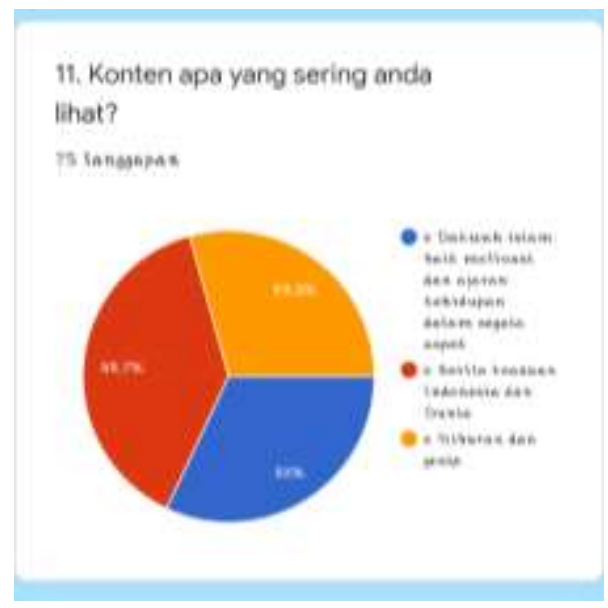

Dari diagram di atas dapat kita simpulkan bahwa konten yang sering dilihat adalah berita keadaan Indonesia dan Dunia yaitu sebanyak 38,7\% atau 29 tanggapan, yang 
kedua dakwah Islam baik motivasi dan ajaran kehidupan dalam segala aspek yaitu sebanyak 32\% atau 24 tangggapan dan ketiga 29,3\% atau sebanyak 22 tanggapan melihat hiburan dan gosip.

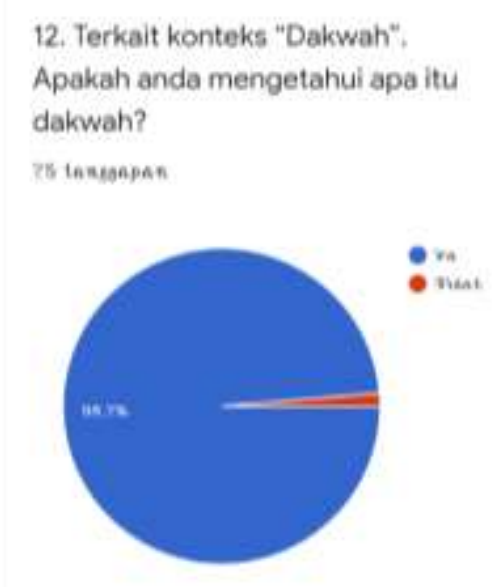

Dapat dilihat hanya satu orang yang tidak mengetahui apa itu dakwah dan mayoritas mengetahui arti dakwah.

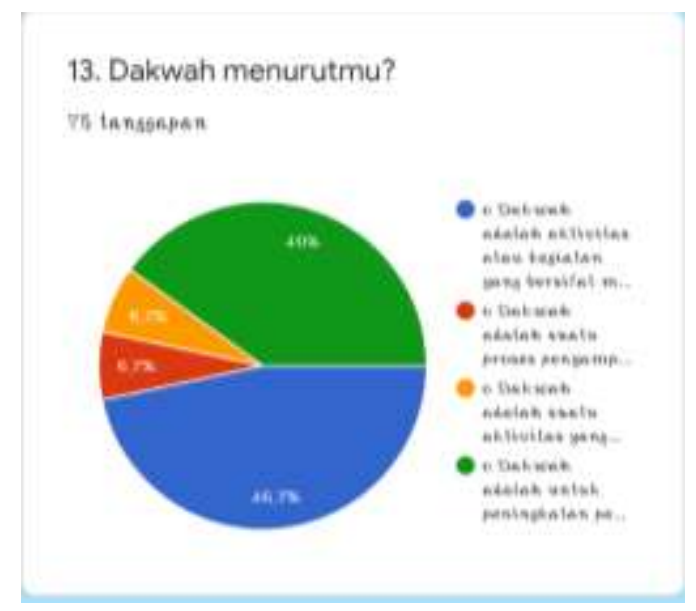

Menurut mereka $46.7 \%$ atau 35 tanggapan mengatakan jika dakwah merupakan kegiatan dan aktivitas yang bersifat mengajak dan menyeru kepada orang lain dalam mengamalkan ajaran Islam. Dan $40 \%$ atau 30 tanggapan mengatakan dakwah adalah untuk peningkatan pemahaman keagamaan dalam mengubah pandangan hidup, sikap batin dan perilaku umat yang tidak sesuai dengan tuntutan syariat untuk memperoleh kebahagiaan hidup di dunia dan di akhirat dan sisanya sebanyak $6,7 \%$ mengatakan jika dakwah merupakan suatu proses penyampaian ajaran Islam yang dilakukan secara sadar dan sengaja. Serta dakwah merupakan 
suatu aktivitas yang pelaksanaannya bisa dilakukan dengan berbagai cara atau metode.

Hal ini sejalan dengan Zuhdi (2017) yang mengungkapkan bahwa dakwah memiliki asal kata dari 'dakwah' yang memiliki pengertian mengajak atau 'ajakan', yang bersumber dari kata Arab, da' $\hat{a}$, yad' $\hat{u}$, da'watan, du'a yang memiliki arti mengajak, memanggil, menyeru, permohonan, dan mengharap manusia agar senantiasa berada di jalan Allah Swt. Dakwah haruslah mengandung tiga unsur, penyampa pesan, informasi yang disampaikan, dan penerima pesan. Secara istilah dakwah mengandung pengertian yang lebih luas, yaitu sebagai aktivitas menyampaikan ajaran Islam, menyuruh berbuat baik, dan mencegah perbuatan mungkar, serta memberi kabar gembira dan peringatan bagi manusia.

Sejalan juga dengan pendapat Mulkhan (Farihah, 2013) mengatakan bahwa, pengertian dakwah sebagai suatu kegiatan sosialisasi Islam yang memiliki berbagai pengertian sebagai berikut:

1. Mendorong manusia agar melakukan kebajikan dan mengikuti petunjuk, menyuruh berbuat kebajikan dan meninggalkan kemunkaran, agar memperoleh kebahagiaan di dunia dan di akhirat.

2. Mengadakan seruan kepada semua manusia untuk kembali dan hidup sepanjang ajaran Allah yang benar, dilakukan dengan penuh kebijaksanaan dan nasehat yang baik.

3. Mengubah umat dari satu situasi kepada situasi yang lebih baik di dalam segala segi kehidupan dengan tujuan merealisasikan ajaran Islam di dalam kenyataan hidup sehari-hari, baik bagi kehidupan seorang pribadi, kehidupan keluarga maupun masyarakat sebagai keseluruhan tata hidup manusia.

4. Menyampaikan panggilan Allah dan Rasul kepada apa yang menghidupkan umat manusia sesuai dengan martabat, fungsi dan tujuan hidupnya.

Menurut Ahmad (2014) menyatakan bahwa dakwah bisa dipahami dengan upaya memberikan solusi terhadap berbagai masalah dalam kehidupan. Sehingga dakwah perlu dikemas melalui cara yang menarik dan tampil secara aktual, faktual, dan kontekstual. Aktual berarti dapat memecahkan masalah-masalah yang kekinian dan hangat di tengah masyarakat. Faktual adalah konkret dan nyata, 
sedangkan kontekstual berarti relevan dengan masalah yang sedang dihadapi oleh masyarakat".

Kegiatan dakwah menurut Habibi (2018) antara lain didasarkan pada Alquran surah An-Nahl ayat (125) yang artinya: "Serulah (manusia) kepada jalan Tuhanmu dengan hikmah dan pelajaran yang baik dan bantahlah mereka dengan cara yang baik. Sesungguhnya Tuhanmu Dialah yanglebih mengetahui tentang siapa yang tersesat dari jalan-Nya dan Dialah yang lebih mengetahui orangorang yang mendapat petunjuk".

Menurut Sofiana (2019) mengemukakan jenis-jenis dakwah diantaranya adalah:

1. Dakwahi Fardiah, merupakan dakwah yang dilakukan seseorang kepadai orang lain.

2. Dakwah Ammah, merupakan dakwah yang dilakukan dengan media lisan kepada banyak orang, seperti pidato.

3. Dakwah bil lisan yaitu metode dakwah yang dilakukan oleh seorang da'i dalam menyampaikan pesan/informasi melalui lisan, yaitu ceramah atau komunikasi yang dilakukan dengan langsung.

4. Dakwah bil hal merupakan seruan dengan mengedepankan perbuatan nyata.

5. Dakwah bit Tadwin yaitu cara dakwah melalui tulisan, baik dalam buku, majalah, internet, dan lain sebagainya.

6. Dakwah bil Hikmah yaitu berdakwah dengan cara arif dan bijaksana, sesuai dengan keilmuan, dan tau siapa yang diajak bicara.

Dilihat dari pengertian dan jenis-jenis dakwah, dapat disimpulkan bahwa dakwah merupakan kegiatan yang bersifat mengajak dan menyeru kepada seseorang untuk dapat mengamalkan ajaran Islam yang dilakukan secara sadar dan sengaja dalam mengubah pandangan hidup, sikap batin dan perilaku umat yang tidak sesuai dengan tuntutan syariat untuk memperoleh kebahagiaan hidup di dunia dan di akhirat yang pelaksanaannya bisa dilakukan dengan berbagai cara atau metode. 


\section{Apakah kamu pernah \\ berdakwah?}

zos tangrapes

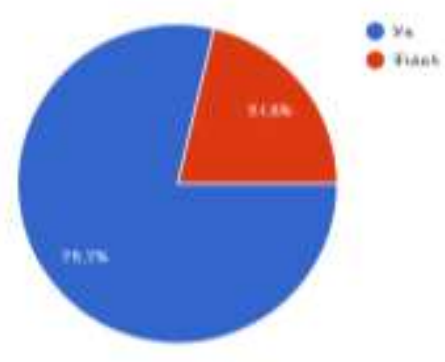

Dapat kita lihat dari gambar di atas yang menunjukan bahwa $78.7 \%$ atau 59 tanggapan pernah berdakwah dan kebanyakan mereka berdakwah melalui media sosial yaitu sebanyak $53.3 \%$ atau 40 tanggapan dan sisanya berdakwah secara langsung/forum terbuka dapat dilihat pada diagram berikut:

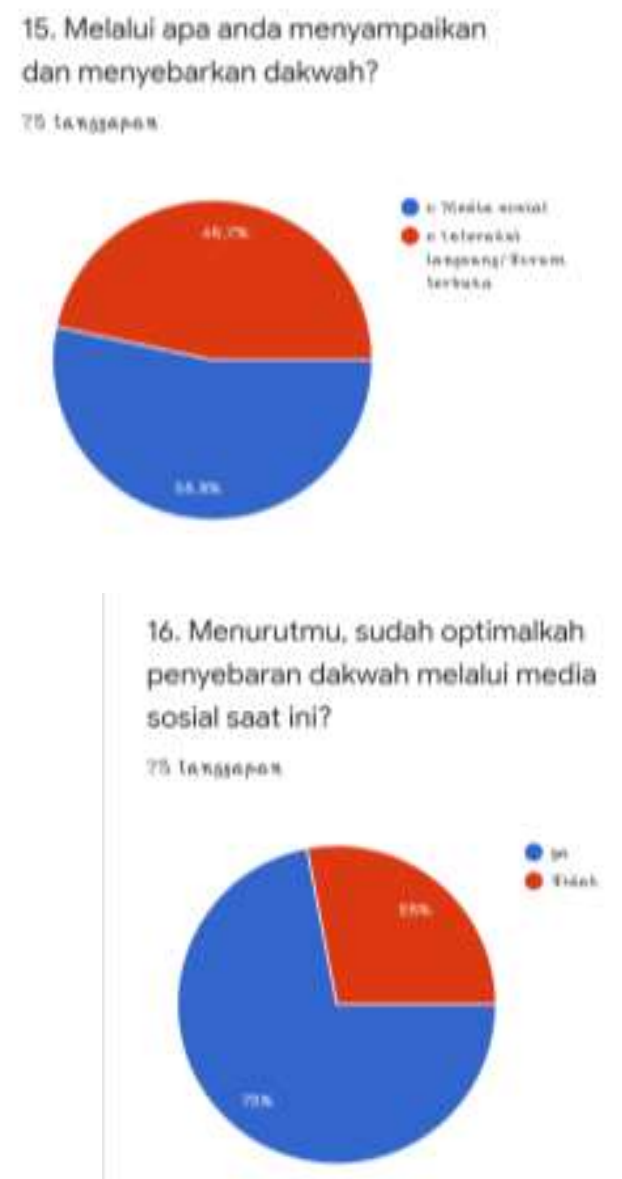

Berdasarkan tanggapan yang diberikan mereka mengatakan bahwa penyebaran dakwah melalui media sosial ini sudah optimal yaitu sebanyak $72 \%$ atau 54 tanggapan mengatakan setuju dan $28 \%$ lainnya tidak dengan alasan sebagai berikut : 


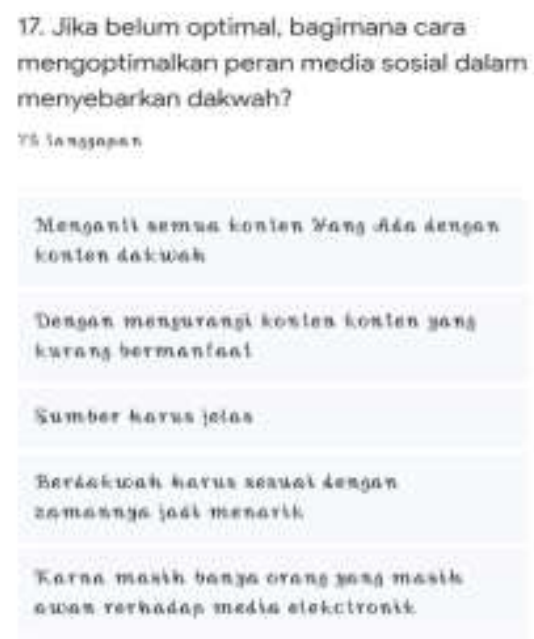

Responden mengungkapkan bahwa penggunaan media sosial yang belum optimal sebagai media untuk melakukan dakwah, karena beralasan bahwa konten yang disajikan masih kurang menarik, pemahaman yang kurang, dan banyak media yang tidak jelas sumbernya.

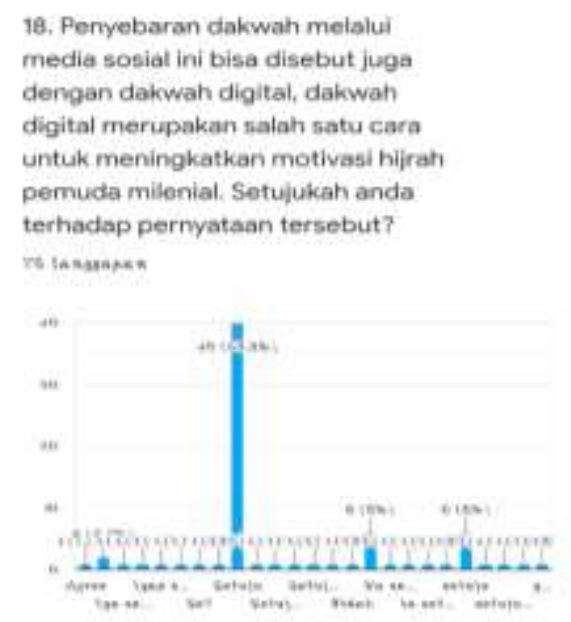

Walau dapat dilihat jika jawaban keseluruhan berbeda beda tapi mayoritas mereka berpendapat setuju dengan pernyataan pada no 18 ini. Dan mereka juga berpendapat cara yang dapat meningkatkan motivasi dalam berhijrah diantaranya mengajak dan membaca serta mengamalkan al-qur'an serta menambah ilmu dan berkumpul dengan orang orang saleh dan terus memperbaiki diri lagi. 


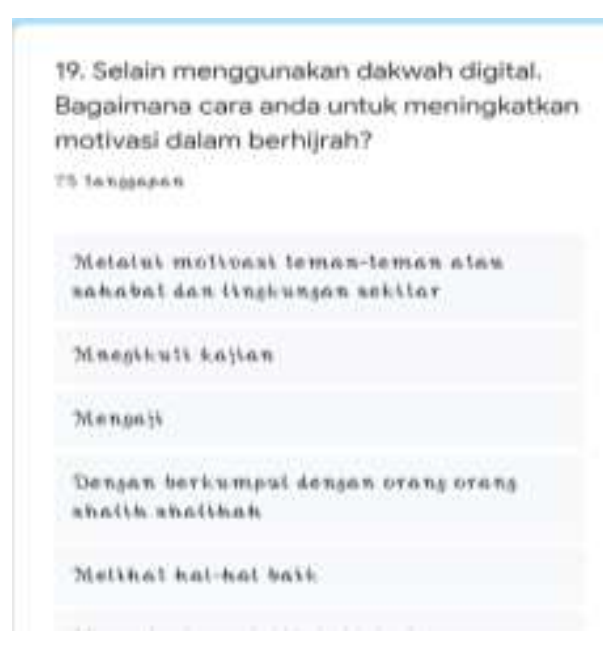

Responden mengungkapkan bahwa motivasi menjadi hal yang penting sebagai alasan banyak orang yang berhijrah. Setiap orang memiliki motif tersendiri untuk berhijrah. Menurut Farhan \& Retnawati (2014) menyebutkan motivasi adalah sebuah dorongan untuk dapat memberi energi kepada orang lain dalam melakukan suatu kegiatan, kemudian membimbingnya supaya tercapai apa yang menjadi tujuannya. Selain itu motivasi dapat diartikan sebagai suatu dorongan untuk melakukan sesuatu dimana dorongan tersebut menjadi pembangkit untuk mencapai tujuannya. Menurut Farabuana \& Nurrahmi (2019) mengemukakan dari pengertian motivasi tersebut, terbagi menjadi dua motivasi "Motivasi untuk dan motivasi karena", motivasi untuk berorientasi ke masa depan sedangkan motivasi karena berorientasi ke masa lalu". Yang kemudian dibedakan menjadi dua kategori yaitu dari dalam individu sendiri dan dari luar individu, dimana terjadinya perubahan menjadi lebih baik lagi dari sebelumnya sehingga tercapai apa yang diharapkan dan dihargai oleh orang lain. Farhan \& Retnawati (2014). Sedangkan menurut Makmun (2007) mengatakan, motivasi itu terjadi karena ada dorongan dari dalam jiwa dan dipengaruhi oleh lingkungannya. Dari hal tersebut motivasi terbagi menjadi dua golongan

1. Motif primer atau yang sering didengar dengan dorongan yang dibedakan menjadi dua yaitu pertama dorongan fisiologis atau bersumber dari kebutuhan organis dan kedua dorongan umum atau bersumber dari luar yang berupa rangsangan seperti rasa takut, kasih sayang, dorongan untuk melarikan diri, dan lainnya. 
2. Motif sekunder yang lebih berorientasi kepada sesuatu berdasar pengalaman atau bisa juga melalui belajar. Contohnya itu motif sosial dimana individu merasa ingin dihargai, ingin diterima dan sebaganya.

Oleh karena itu setiap gerak perilaku manusia dari segi motifnya mengandung tiga aspek yakni: 1). Motivatingi states; 2). Motivated behavior; dan 3). Satisfied conditions. Jadi dapat disimpulkan motivasi merupakan sebuah bentuk dorongan baik dari dalam diri sendiri maupun luar untuk melakukan sesuatu sehingga menjadi penyemangat untuk mencapai apa yang diinginkan

\section{Kesimpulan}

Hasil penelitian menunjukan bahwa motivasi hijrah merupakan sebuah dorongan kepada seseorang untuk menjadi pribadi yang lebih baik. Peningkatkan motivasi hijrah lebih banyak atas dorongan dari faktor internal sebelum didukung oleh motivasi dari eksternal. Hasil penelitian menunjukkan peningkatan motivasi hijrah milenial melalui media sosial mencapai $72 \%$. Dengan demikian media sosial sangat efektif dalam menyebarkan dakwah bagi kaum milenial. Media sosial yang tidak terbatas ruang dan waktu sehingga bisa diakses kapan saja dan dimana saja berdampak positif bagi kalangan milenial ketika digunakan dengan bijak dan tidak berlebihan. Tetapi sebaliknya media sosial akan berdampak negatif ketika kelompok milenial mulai ketergantungan dan cenderung mengabaikan aspek kehidupan sosial dilingkungannya.

\section{Referensi}

Ahmad, N. (2014). Tantangan Dakwah Di Era Teknologi Dan Informasi: Formulasi Karakteristik, Popularitas, Dan Materi Di Jalan Dakwah. dalam Jurnal Addin STAIN Kudus, 8 (2), 319-334.

Budiono, A. (2019). Hijrah Dalam Perspektif Tafsir Sya'rawi: Sebuah Kajian Tafsir Tematik. Miyah: Jurnal Studi Islam, 15 (01), 57-80.

Cahyono, A. S. (2016). Pengaruh media sosial terhadap perubahan sosial masyarakat di Indonesia. Jurnal Publiciana, 9 (1), 140-157.

Farabuana, P., \& Nurrahmi, F. (2019). Motivasi dan Perilaku Hijrah Followers Akun Istagram Pemuda Hijrah Pada Mahasiswa Universitas Syiah Kuala. Jurnal Ilmiah Mahasiswa FISIP Unsyiah, 4 (3), 1-16. 
Farhan, M., \& Retnawati, H. (2014). Keefektifan Pbl Dan Ibl Ditinjau Dari Prestasi Belajar, Kemampuan Representasi Matematis, Dan Motivasi Belajar. Jurnal Riset Pendidikan Matematika, 1(2), 227-240.

Farihah, I. (2013). Media Dakwah Pop. AT-TABSYIR; Jurnal Komunikasi Penyiaran Islam, 1(2), 25-45.

Fitri, R., \& Jayanti, I. (2020). Fenomena Seleb Hijrah: Tendensi Ekslusivisme dan Kemunculan Kelompok Sosial Baru. MUHARRIK: Jurnal Dakwah Dan Sosial, 3(01), 1-17.

Fitri, S. (2017). Dampak positif dan negatif sosial media terhadap perubahan sosial anak. Naturalistic: Jurnal Kajian Penelitian Pendidikan dan Pembelajaran, 1(2), 118-123.

Habibi, M. (2018). Optimalisasi Dakwah Melalui Media Sosial Di Era Milenial. AlHikmah: Jurnal Dakwah, 12(1), 101-116.

Makmun, A. S. (2007). Psikologi Kependidikan. Bandung: PT Remaja Rosdakarya Offset.

Nasrullah, Rulli. (2017). Media Sosial : Perspektif Komunikasi, Budaya, dan Sosioteknologi. Bandung: Remaja Rosdakarya.

Parhan, M. Sutedja, B (2019). Penerapan Pendekatan Pembelajaran Kontekstual dalam Pendidikan Agama Islam di Universitas Pendidikan Indonesia. TARBAWY: Indonesian Journal of Islamic Education. Vol. 6 (2). 114-126.

Qodariah, S., dkk. (2018). Hubungan self-control dengan murū'ah pada anggota Gerakan Pemuda Hijrah di Masjid TSM Bandung. Jurnal Psikologi Islam, 4(2), hlm. 205-212.

Rubawati, E. (2018). Media Baru: Tantangan dan Peluang Dakwah. Jurnal Studi Komunikasi. Vol. 2 No. 1. 126-142.

Sarbani, A. (2010). Paradigma Baru Pemikiran Dakwah Islam. Jurnal Ilmu Dakwah Vol. 4 No. 15. 879-896.

Setiawati, K. (2019). Hijrah Baru di Kalangan Anak Muda antara Keshalehan dan Gaya Hidup. (Skripsi). Darussalam Banda Aceh: Universitan Islam Negeri ArRaniry.

Sofiana, L. (2019). Metode Dakwah (Pengertian, Hukum, Metode dan Jenis). https://www.kompasiana.com/linda25926/5dcfaea4d541df0df212cec3/konsep- 
dakwah-pengertian-hukum-metode-dan-jenis-dakwah. Diakses 30 Maret 2020.

Ummah, A. H. (2020). Dakwah Digital dan Generasi Milenial (Menelisik Strategi Dakwah Komunitas Arus Informasi Santri Nusantara). Tasamuh: Dakwah dan Komunikasi. Volume 18, No. 1. 54-78.

Utomo, W. P. (2013). Menimbang media sosial dalam marketing politik di Indonesia: belajar dari Jokowi-Ahok di Pilkada DKI Jakarta 2012. Jurnal Ilmu Sosial dan Ilmu Politik, 17(1), 67-84.

Wibowo, A. (2019). Penggunaan Media Sosial Sebagai Trend Media Dakwah Pendidikan Islam di Era Digital. Jurnal Islan Nusantara. Vol.3 no 2. 339-356.

Zuhdi, M. H. (2017). Dakwah Dan Dialektika Akulturasi Budaya. Religia,15(1). 46-64. 